\title{
Dry Matter Production, Agro-Meterological Indices of Rice As Influenced By Methods of Establishment and Transplanting Dates
}

\author{
Chandrashekhar $^{1 *}$, M. Hanumanthappa ${ }^{2}$, S. Sridhara ${ }^{1}$ and R. Jayaprakash ${ }^{3}$ \\ ${ }^{1}$ Department of Agronomy, College of Agriculture, University of Agricultural and \\ Horticultural Sciences, Shivamogga, Karnataka, India \\ ${ }^{2}$ Department of Hort., College of Horticulture, Mudigere, Chickmagalur, Karnataka, India \\ ${ }^{3}$ Department of Soil Science \& Agriculture Chemistry, KVK, Brahmavar, Udupi, Karnataka, \\ India
}

\section{A B S T R A C T}

\begin{tabular}{|c|}
\hline Keywords \\
\hline $\begin{array}{l}\text { Rice, Dry matter, Heat } \\
\text { use efficiency, Photo } \\
\text { thermal use efficiency, } \\
\text { Helio thermal use } \\
\text { efficiency and Radiation } \\
\text { use efficiency }\end{array}$ \\
\hline Article Info \\
\hline $\begin{array}{l}\text { Accepted: } \\
08 \text { August } 2018 \\
\text { Available Online: } \\
10 \text { September } 2018\end{array}$ \\
\hline
\end{tabular}

\section{Introduction}

The world as we know today would change in many exciting ways by the year 2050. The world's population would exceed nine billion, average global temperature would rise, sea levels may go up, crop diversification with different technology may rule as dictated by shifting of rainfall and drought situations. As a result, most importantly, the world would be running out of necessities like food, fodder and fuel (Fan and Brzeska, 2010). Rice (Oryza sativa $\mathrm{L}$.) is the most important staple food for
An field experiment was conducted during kharif 2017 at ZAHRS, Brahmavara to examine the response of two rice establishment methods viz., Conventional method $(20 \mathrm{~cm} \times 10$ $\mathrm{cm})$ and SRI method $(25 \mathrm{~cm} \times 25 \mathrm{~cm})$ with five dates of transplanting viz., $3^{\text {rd }}$ week of June, $1^{\text {st }}$ week of July, $3^{\text {rd }}$ week of July, $1^{\text {st }}$ week of August and $3^{\text {rd }}$ week of August. Observations were recorded in 15 days interval until crop reaches physiological maturity. The experiment was conducted by using split plot design and the treatments were replicated thrice. Results indicates that significantly higher dry matter accumulation of rice was observed in SRI method of establishment as compared to conventional method of establishment and among the dates of transplanting, $3^{\text {rd }}$ week transplanting has recorded higher dry matter accumulation, efficiencies like heat use efficiency, photo thermal use efficiency and helio thermal use efficiency at physiological maturity. Higher radiation use efficiency in $3^{\text {rd }}$ week of transplanting might be due to better conversion of light energy in to dry matter and better yield as compared to delay transplanting. 
at optimum date has longer growth duration which consequently provides an opportunity to accumulate more biomass as compared to late transplanting (Singh and pal, 2003). To study the comparative utilization these natural resources some weather based agro meteorological indices have been developed. The commonly used weather based agro meteorological indices are Heat use efficiency (HUE), Photo thermal use efficiency (PTUE), Helio thermal use efficiency (HTUE), and Radiation use efficiency (RUE) are the most common temperature indices used to determine plant development. Hence, the investigation was undertaken to know the heat unit requirements and dry matter production of rice transplanted on different dates and different planting methods.

\section{Materials and Methods}

Field experiment was conducted at Zonal Agricultural and Horticultural Research Station, Brahamavara, $\left(13^{0} 24^{\prime} \mathrm{N}\right.$ latitude and $74^{0} 45^{\prime}$ E longitude with an altitude of $10 \mathrm{~m}$ above sea level) during kharif season 2017 in the sandy loam soil, slightly acidic in reaction $(\mathrm{pH} 5.30)$, medium in organic carbon $(1.28 \mathrm{~g}$ $\mathrm{kg}^{-1}$ ) as well as in available nitrogen (318.11 $\left.\mathrm{kg} \mathrm{ha}^{-1}\right)$ and available potassium $(158.12 \mathrm{~kg}$ $\mathrm{ha}^{-1}$ ), and high in available phosphorous (46.89 $\left.\mathrm{kg} \mathrm{ha}^{-1}\right)$. Experiment was laid out in Split-plot design with replicated thrice.

Two main treatments viz., Conventional method $\left(\mathrm{M}_{1}\right)$ and System of Rice Intensification $\left(\mathrm{M}_{2}\right)$ method. Five dates of transplanting as subplots viz., June $3^{\text {rd }}$ week, July $1^{\text {st }}$ week, July $3^{\text {rd }}$ week, August $1^{\text {st }}$ week and August $3^{\text {rd }}$ week. The soil of experimental field was sandy loam and acidic in nature. Thirteen days old seedling of rice (var. MO-4) were transplanted at $20 \mathrm{~cm} \times 10 \mathrm{~cm}$ spacing for conventional method and for SRI method 21 days old seedling were transplanted at 25 $\mathrm{cm} \times 25 \mathrm{~cm}$. The recommended fertilizer dose for rice under coastal condition is $60: 30: 60 \mathrm{~kg}$ $\mathrm{N}: \mathrm{P}_{2} \mathrm{O}_{5}: \mathrm{K}_{2} \mathrm{O} \mathrm{ha}^{-1}+20 \mathrm{~kg}$ Zinc sulphate per hectare +10 tonnes of FYM per hectare (Package of practice, UAS, Bengaluru). Nitrogen and potash fertilizers are applied at three and two splits respectively, in first split 50 per cent of recommended Nitrogen with full dose of phosphorous and 50 per cent of recommended potash fertilizer applied at the time of transplanting as basal dose, in second split Nitrogen fertilizer applied at 30 DAT and third split nitrogen and potash fertilizer applied 60 at DAT. The GDD, PTU, HTU, PAR and HUE were computed by using following formula:

\section{Heat use efficiency (HUE)}

Heat use efficiency for total dry matter was obtained as under

Heat use efficiency $=\frac{\text { Total dry matter }\left(\mathrm{g} \mathrm{plant}^{-1}\right)}{\sum \mathrm{GDD}}$

\section{Photo thermal use efficiency (PTUE)}

Photo thermal unit (PTU) is calculated by multiplying GDD with maximum possible sunshine hours $(\mathrm{N})$.

$\mathrm{PTU}=\mathrm{GDD} \times \mathrm{X}$

Where,

$\mathrm{N}=$ maximum possible sunshine hour.

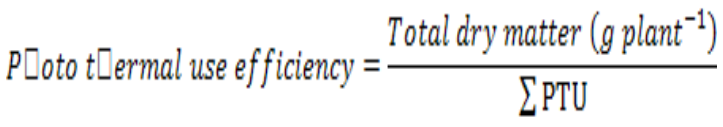

\section{Helio thermal use efficiency (HTUE)}

Helio thermal unit (HTU) is calculated by multiplying GDD with actual sunshine hours.

Helio thermal unit $=$ GDD $X \mathrm{n}$ 
Where,

$\mathrm{n}=$ actual sunshine hour.

Helio thermal use efficiency $=\frac{\text { Total dry matter } g \text { plant }{ }^{-1}}{\sum H T U}$

\section{Radiation use efficiency}

It is defined as the amount of dry matter produced per unit of solar radiation or incoming PAR or intercepted PAR and expressed as $\mathrm{g} \mathrm{MJ}^{-1}$ Kiniry et al., (1989).

Radiation use efficiency $=\frac{\text { Total dry matter }\left(\mathrm{g} \mathrm{m}^{-2}\right)}{\sum \operatorname{IPAR}\left(\mathrm{MJ} \mathrm{m} \mathrm{m}^{-2}\right)}$

Where,

$\sum$ IPAR $=$ Cumulative intercepted photo synthetically active radiation.

The data was analyzed by adapting Fischer's method of analysis of variance as outlined by Gomez and Gomez, 1984.

\section{Results and Discussion}

The pre requisite for getting higher yields in any crop is higher total dry matter production (TDM) and its partitioning into various plant parts coupled with maximum translocation of photosynthates to the sink. Total dry matter partitioning into individual plant parts depends on various environmental factors influencing growth are $\mathrm{Co}_{2}$ concentration interception of photosynthetically active radiation, air, leaf temperature, relative humidity and soil moisture availability.

In the present study, total dry matter production was found to increase with the advance of crop growth, attaining maximum at harvest irrespective of method of establishment. At harvest, total dry matter accumulation $\left(\mathrm{g} \mathrm{hill}^{-1}\right)$ influenced significantly due to systems of crop establishment. Among different systems of establishment, SRI recorded significantly higher total dry matter accumulation $\quad\left(75.92 \mathrm{~g} \quad\right.$ hill $\left.^{-1}\right)$ over conventional methods. It was about 46 per cent higher total dry matter accumulation as compared to conventional method of rice establishment at harvest. Date of transplanting approaches also influenced significantly on total dry matter accumulation, in that significantly higher total dry matter accumulation were recorded in $3^{\text {rd }}$ week of June (77.01 $\left.\mathrm{g} \mathrm{hill}{ }^{-1}\right)$ compared to $3^{\text {rd }}$ week of July (68.13 $\left.\mathrm{g} \mathrm{hill}^{-1}\right), 1^{\text {st }}$ week of August (58.36 $\mathrm{g} \mathrm{hill}{ }^{-1}$ ) and $3^{\text {rd }}$ week of August (41.21 g hill $\left.^{-1}\right)$, it was on par with $1^{\text {st }}$ week of July (74.95 $\left.\mathrm{g} \mathrm{hill}^{-1}\right)$.

This might be due to higher solar radiation interception in SRI method of establishment, it enhanced the efficiencies like radiation use efficiency, heat use efficiency and photo thermal use efficiency. These results are in conformity with the findings of Patar and Sahu (2007).

SRI method of establishment was found more efficient in utilizing available natural resources and recorded higher Heat use efficiency $\left(4.24 \times 10^{-2} \mathrm{~g}^{0} \mathrm{C}\right.$ day $\left.^{-1}\right)$, photo thermal use efficiency $\left(8.32 \times 10^{-2} \mathrm{~g}^{0} \mathrm{C} \mathrm{day}^{-1}\right)$, helio thermal use efficiency $\left(11.21 \times 10^{-3} \mathrm{~g}^{0} \mathrm{C}\right.$ $\mathrm{hrs}^{-1}$ ) and Radiation use efficiency (3.27 $\mathrm{g}$ $\mathrm{MJ}^{-1}$ ). The higher use efficiency shows the efficient dry matter portioning to various plant parts. This was in accordance with Saha et al., (2010) and Takeshihorie et al., (2003).

Among the date of transplanting, June $3^{\text {rd }}$ week of transplanting recorded higher Heat use efficiency $\left(4.34 \times 10^{-2} \mathrm{~g}^{0} \mathrm{C} \mathrm{day}^{-1}\right)$, photo thermal use efficiency $\left(8.32 \times 10^{-2} \mathrm{~g}^{0} \mathrm{C} \mathrm{day}^{-1}\right)$, helio thermal use efficiency $\left(15.29 \times 10^{-3} \mathrm{~g}^{0} \mathrm{C}\right.$ $\mathrm{hrs}^{-1}$ ) and Radiation use efficiency (3.03 g $\mathrm{MJ}^{-1}$ ) (Table 1 and 2). 
Table.1 Total dry matter accumulation $\left(\mathrm{gm} \mathrm{hill}^{-1}\right)$ of rice at different growth stages as influenced by date of transplanting under different methods of establishment

\begin{tabular}{|c|c|c|c|c|c|c|c|c|}
\hline Treatment & $\begin{array}{c}15 \\
\text { DAT }\end{array}$ & $\begin{array}{c}30 \\
\text { DAT }\end{array}$ & $\begin{array}{c}45 \\
\text { DAT }\end{array}$ & $\begin{array}{c}60 \\
\text { DAT }\end{array}$ & $\begin{array}{c}75 \\
\text { DAT }\end{array}$ & $\begin{array}{c}90 \\
\text { DAT }\end{array}$ & $\begin{array}{c}105 \\
\text { DAT }\end{array}$ & $\begin{array}{c}\text { At } \\
\text { harvest }\end{array}$ \\
\hline \multicolumn{9}{|c|}{ Crop establishment (M) } \\
\hline $\mathrm{M}_{1}$ :Conventional method & 1.07 & 3.93 & 9.19 & 17.42 & 26.82 & 38.29 & 47.61 & 51.95 \\
\hline $\mathrm{M}_{2}: \mathrm{SRI}$ & 1.43 & 4.96 & 16.61 & 28.92 & 38.43 & 53.93 & 72.19 & 75.92 \\
\hline S.Em. \pm & 0.25 & 0.13 & 0.12 & 0.70 & 0.67 & 0.73 & 1.03 & 1.27 \\
\hline C. D. at $\mathbf{5 \%}$ & NS & 0.38 & 0.35 & 2.08 & 1.99 & 2.17 & 3.06 & 3.78 \\
\hline \multicolumn{9}{|c|}{ Time of transplanting (S) } \\
\hline$S_{1}: 3^{\text {rd }}$ week of June & 1.15 & 4.96 & 14.96 & 28.61 & 40.76 & 57.43 & 74.55 & 77.01 \\
\hline$S_{2}: 1^{\text {st }}$ week of July & 1.08 & 4.73 & 14.15 & 27.35 & 39.25 & 55.41 & 72.55 & 74.95 \\
\hline$S_{3}: 3^{\text {rd }}$ week of July & 1.12 & 4.43 & 13.11 & 24.54 & 35.60 & 49.26 & 63.31 & 68.13 \\
\hline$S_{4}: 1^{\text {st }}$ week of August & 1.07 & 4.21 & 12.25 & 20.35 & 27.56 & 40.05 & 52.75 & 58.36 \\
\hline$S_{5}: 3^{\text {rd }}$ week of August & 1.81 & 3.86 & 9.78 & 14.98 & 19.95 & 28.38 & 36.35 & 41.21 \\
\hline S. Em. \pm & 0.34 & 0.27 & 0.45 & 1.25 & 1.33 & 1.71 & 1.78 & 1.77 \\
\hline C. D. at $5 \%$ & NS & NS & 1.35 & 3.76 & 4.00 & 5.14 & 5.33 & 5.32 \\
\hline
\end{tabular}

Table.2 Heat use efficiency $\left(\mathrm{g}^{0} \mathrm{C}\right.$ day $\left.^{-1}\right) \times 10^{-2}$, Photo thermal use efficiency $\left(\mathrm{g}^{0} \mathrm{C} \mathrm{day}^{-1}\right) \times 10^{-2}$, Helio thermal use efficiency $\left(\mathrm{g}^{0} \mathrm{C}_{\text {day }}{ }^{-1}\right) \times 10^{-3}$, and Radiation use efficiency $\left(\mathrm{g} \mathrm{MJ}^{-1}\right)$ of rice as influenced by date of transplanting under different methods of establishment

\begin{tabular}{|c|c|c|c|c|}
\hline Treatment & HUE & PTUE & HTUE & RUE \\
\hline \multicolumn{5}{|l|}{ Crop establishment (M) } \\
\hline $\begin{array}{l}\mathrm{M}_{1} \text { :Conventional } \\
\text { method }\end{array}$ & 2.90 & 5.69 & 7.72 & 2.54 \\
\hline $\mathrm{M}_{2}: \mathrm{SRI}$ & 4.24 & 8.32 & 11.21 & 3.27 \\
\hline S.Em. \pm & 0.07 & 0.13 & 0.21 & 0.08 \\
\hline C. D. at $5 \%$ & 0.20 & 0.38 & 0.62 & 0.25 \\
\hline \multicolumn{5}{|c|}{ Time of transplanting (S) } \\
\hline$S_{1}: 3^{\text {rd }}$ week of June & 4.34 & 8.32 & 15.29 & 3.03 \\
\hline$S_{2}: 1^{\text {st }}$ week of June & 4.17 & 8.11 & 11.61 & 2.81 \\
\hline$S_{3}: 3^{\text {rd }}$ week of July & 3.77 & 7.42 & 8.72 & 2.92 \\
\hline $\mathrm{S}_{4}: 1^{\mathrm{st}}$ week of August & 3.22 & 6.43 & 6.93 & 3.09 \\
\hline$S_{5}: 3^{\text {rd }}$ week of August & 2.33 & 4.72 & 4.74 & 2.64 \\
\hline S. Em. \pm & 0.09 & 0.19 & 0.25 & 0.09 \\
\hline C. D. at $5 \%$ & 0.29 & 0.58 & 0.77 & 0.28 \\
\hline
\end{tabular}


Fig.1 Extent of reduction in grain yield due to delay in transplanting

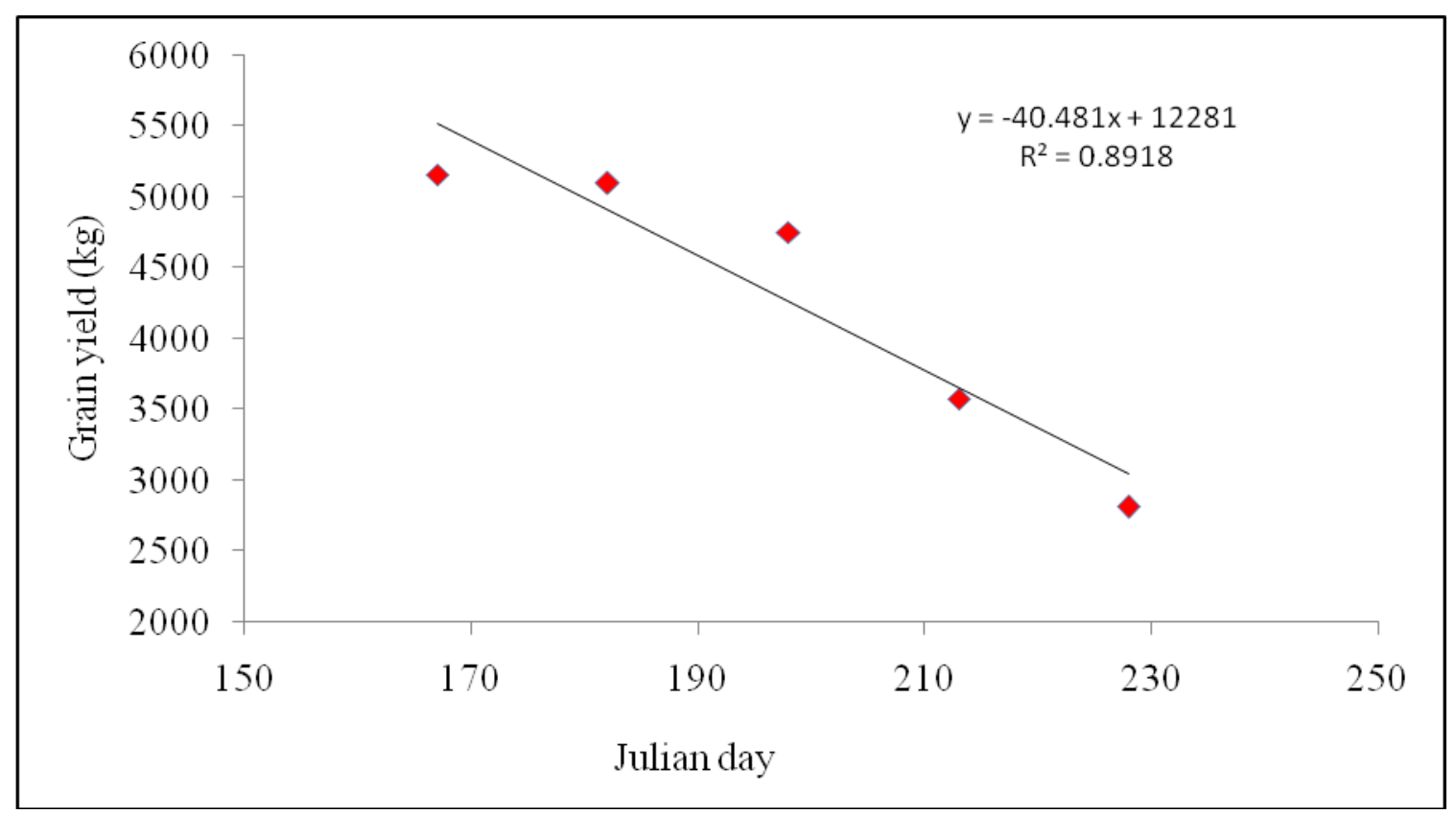

It was due to early transplantation has taken advantage of optimum temperature and sunlight during the early stages of plant development and there by avoided adverse situation during its life cycle. It resulted in crop transplanted on June $3^{\text {rd }}$ week received sufficient and uniform distribution of rainfall and experience optimum weather condition throughout its growth stages. This resulted in higher grain yield (5159 kg ha-1) which was about 1.1 per cent to 45.40 per cent more yield as compared to other dates of transplanting (Fig. 1). These results are in conformity with the findings of Praveen et al., (2013) and Welch et al., (2010).

\section{References}

Fan, S. and Brzeska, J. 2010. The role of emerging countries in global food security. International Food Policy Research Institute, IFPRI Policy Brief, p. 15.

Gomez, K. A. and Gomez, A. A. 1984. In: Statistical procedures for agricultural research. Second Edn. John Wiley and Sons, New York. p. 68.
Khush, G. S. 2004. Harnessing science and technology for sustainable rice-based production systems. Proceedings of FAO Rice Conference "Rice is life". International Rice Communication Newsletter. 53: 17-23.

Kiniry, J. R., Ritchie, J. T., and Musser, R. L. 1989. Dynamic nature of the photoperiod response in maize. Agronomy Jouranl. 75: 700-703.

Patra, B. K., and Sahu, D. D. 2007. Use of agrometeorological indices for suitable sowing time of wheat under South Saurashtra agroclimatic Zone of Gujarat. Journal of Agrometerology. 9(1): 74-80.

Praveen. K. V., Patel. S. R., Choudhary. J. L., and Bhelawe, S. 2013. Heat unit requirement of different rice varieties under Chhattisgarh plain Zones of India. Journal of Agrometerology. 5(1): 123127.

Saha, A., and Bharti. V. 2010. Effect of different crop establishment methods on growth, yield and economics of rice 
(Oryza sativa L.). Environmental Ecology. 28(1): 519-522.

Singh, S., and M. Pal. 2003. Growth, yield and phonological response of wheat cultivars to delayed sowing. Indian Journal of Plant Physiology. 8: 277-287.

Takeshihorie, Koki Homma., and Hiroe Yoshida. 2003. SRI practices in Japan. Proceedings of Crop Science, Japan. 40: 90-94.
Welch, J. R., Vincent, J. R., Auffhammer, M., Moya, P. F., Dobermann, A., and Dawe, D. 2010. Rice yields in tropical/subtropical Asia exhibit large but opposing sensitive to minimum and maximum temperatures. Proceedings of the national academy of science of the United States of America. 107(33): 14562-14567.

\section{How to cite this article:}

Chandrashekhar, M. Hanumanthappa, S. Sridhara and Jayaprakash, R. 2018. Dry Matter Production, Agro-Meterological Indices of Rice As Influenced By Methods of Establishment and Transplanting Dates. Int.J.Curr.Microbiol.App.Sci. 7(09): 913-918.

doi: https://doi.org/10.20546/ijcmas.2018.709.110 